\title{
Działania Organizacji Narodów Zjednoczonych na rzecz dekolonizacji i pokoju w Saharze Za- chodniej
}

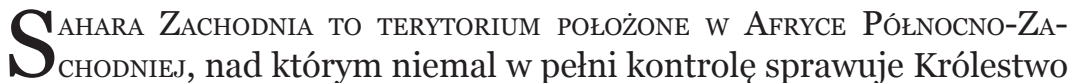
Marokańskie. Trudno o jednoznaczne scharakteryzowanie obecnej sytuacji politycznej Sahary Zachodniej. Jest ona określana przez niektórych publicystów jako ostatnia kolonia afrykańska ${ }^{1}$. Jednak jest to raczej zabieg retoryczny. Względem tego obszaru Maroko pełni funkcję podobną do metropolii z epoki kolonializmu - roztacza ono dominację i kontrolę nad Saharą Zachodnią, eksploatuje ją gospodarczo, a nawet prowadzi szeroko zakrojone programy osadnicze, sprowadzając w wielkiej liczbie Marokańczyków na tereny zamieszkane pierwotnie przez Saharyjczyków (Rice, 2010, s. 32). To, co sprawia, że nie określa się Sahary Zachodniej mianem kolonii pomimo tych podobieństw, to z jednej strony umiejscowienie w czasie (koniec epoki kolonialnej) i w przestrzeni (niemożność zakwalifikowania Maroka do mocarstw kolonialnych ze względu na odmienne uwarunkowania geopolityczne i postkolonialny charakter państwa). Z drugiej strony powodem konsekwentnego unikania określenia Sahary Zachodniej mianem kolonii jest jej przypuszczalnie efektywny rząd funkcjonujący jako Saharyjska Arabska Republika Demokratyczna (SARD). Przypuszczalnie dlatego że dotąd nie miał on okazji do wykazania, że jest w stanie sprawować faktyczną kontrolę nad ludnością i terytorium innym niż pojedyncze osady położone w głębi pustyni i obozy uchodźców na terytorium wydzierżawionym przez Algierię. Ze względu na ten rząd, który dysponuje własną siłą zbrojną, należy mówić o Saharze Zachodniej raczej jako o terytorium okupowanym niż o kolonii ${ }^{2}$, choć nigdy ze stadium kolonii do stadium niezależnego państwa to terytorium nie przeszło.

${ }^{1}$ Zob. (Rice, 2010, s. 28), (Clifford, 2015), (Connett, 2016), (Güell, 2015).

${ }^{2}$ Do konstrukcji terytorium okupowanego względem Sahary Zachodniej odwołuje się także Trybunał Sprawiedliwości Unii Europejskiej (Connett, 2016). 
Organizacja Narodów Zjednoczonych od wielu dekad zmierza do zapewnienia warunków ludności saharyjskiej do emancypacji politycznej i samookreślenia - w szczególności na drodze powszechnego referendum, co do politycznego statusu Sahary Zachodniej. Samą Saharę Zachodnią ONZ zaklasyfikowała jako terytorium niesamodzielne - czyli takie, które na mocy postanowień rozdziału XI Karty Narodów Zjednoczonych - powinno ulec dekolonizacji. Niniejszy artykuł ma na celu omówienie roli Organizacji Narodów Zjednoczonych w długim procesie dekolonizacji Sahary Zachodniej. Mimo że działania ONZ prowadzone w tym zakresie nie osiągnęły ostatecznego celu, to zdołały doprowadzić do zawieszenia broni pomiędzy stronami saharyjskiej wojny wyzwoleńczej oraz do ograniczenia represji wymierzonych w ludność cywilną. Działania te wymusiły również wiele ustępstw na administracji marokańskiej i przygotowały grunt pod przeprowadzenie ewentualnego referendum wśród Saharyjczyków, które powinno ostatecznie zadecydować o losie okupowanego terytorium.

Od czasu zawieszenia broni w 1991 r. pomiędzy Królestwem Marokańskim i Saharyjczykami, nadzorowanego przez misję pokojową ONZ, Maroko utrzymuje status quo, nie dopuszczając do wyzwolenia obszarów Sahary, które zagarnęło w posiadanie. Wysokie koszty okupacji, zarówno polityczne, jak i finansowe, ponoszone przez Maroko są rekompensowane przez bogate złoża fosforanów wydobywanych na terenie Sahary Zachodniej. Ponadto posiadanie tego pustynnego - i jałowego z punktu widzenia gospodarki rolnej - terytorium umożliwia generowanie znacznych dochodów z połowu ryb, na odpowiednich dla Sahary Zachodniej, wodach terytorialnych i wyłącznej strefy ekonomicznej.

Niska skuteczność presji międzynarodowej wywieranej nie tylko przez Organizację Narodów Zjednoczonych, lecz także m.in. przez Unię Afrykańską (do 2002 r. jako Organizację Jedności Afrykańskiej) oraz Ruch Państw Niezaangażowanych wynika z braku poparcia tej presji przez światowe mocarstwa. Związek Socjalistycznych Republik Radzieckich, pomimo zdecydowanych deklaracji antykolonialnych, nie angażował się w konflikt o Saharę Zachodnią. Natomiast dla Stanów Zjednoczonych Królestwo Marokańskie było potencjalnym sojusznikiem - w okresie zimnej wojny przeciwko proradzieckiej orientacji państw arabskiego socjalizmu, a współcześnie przeciwko terroryzmowi i muzułmańskiemu ekstremizmowi (Saidy, 2011, s. 86 - 92). Życzliwą postawę wobec działań Maroka utrzymuje także Republika Francuska (Williams, 2015, s. 22 - 23). 


\section{GeneZa Konfliktu o SAHARE Zachodnią}

TERENy WSPÓECZESNEJ SAHARY ZaChodNiEJ POZOSTAWAEY POZA ZAINTERESOWANIEM mocarstw kolonialnych aż do drugiej połowy XIX w. Wówczas Królestwo Hiszpanii podjęło pierwsze kroki dla zajęcia terytorium Sahary, by uprzedzić III Republikę Francuską i Zjednoczone Królestwo Wielkiej Brytanii i Irlandii - gdyby bowiem one objęły Saharę w posiadanie, stworzyłoby to niebezpieczeństwo dla hiszpańskich Wysp Kanaryjskich. W grudniu 1884 r. Hiszpania ogłosiła swój protektorat nad ziemiami Sahary Zachodniej, jednakże bez sprawowania faktycznej kontroli. W głębi lądu koczownicze plemiona arabskie w pierwszej połowie XX w. podejmowały wyprawy łupieżcze na francuskie terytoria kolonialne, którym kres przyniosła w 1934 r. francuska wyprawa karna (Hodges, 1984, s. 81).

Odzyskanie niepodległości przez Królestwo Marokańskie w 1956 r., które objęło także Maroko Hiszpańskie, stanowiło bodziec dla administracji hiszpańskiej do rozszerzenia kontroli nad Saharą Zachodnią. W 1958 r. pozostała przy Hiszpanii część Sahary stała się hiszpańską prowincją ze stolicą w al-Ujun (Al-uyun). Sahara Hiszpańska była odtąd prowincją zmilitaryzowaną, zarządzaną przez gubernatorów w stopniu generała, w której stacjonowała Hiszpańska Legia Cudzoziemska (Hodges, 1984, s. 81-83). Obecność wojskowa Hiszpanów nie powstrzymała organizujących się ruchów wyzwoleńczych. 20 marca 1973 r. ${ }^{3}$ wojnę partyzancką przeciwko Hiszpanii podjął nowo uformowany Front Polisario (Frente Popular para la Liberacion de Saguia el Hamra y Rio de Oro, Ludowy Front Wyzwolenia Sakiji al-Hamry i Rio de Oro) (Pabst, 2012, s. 71-72).

Po raz pierwszy Organizacja Narodów Zjednoczonych zwróciła się do Hiszpanii bezpośrednio w sprawie Sahary Zachodniej w rezolucji wydanej przez Zgromadzenie Ogólne Narodów Zjednoczonych w 1965 r. Organizacja odwołała się w niej do rezolucji nr 1514 - Deklaracji w sprawie przyznania niepodległości krajom i narodom kolonialnym z 14 grudnia 1960 r. ${ }^{4}$. Na tej podstawie ONZ wezwała rząd hiszpański do niezwłocznego podjęcia negocjacji dotyczących wyzwolenia Hiszpańskiej Sahary i Ifni z dominacji kolonialnej. (Resolution 2072, 1965). O ile sprawa Ifni była stosunkowo jasna - ludność chciała

${ }^{3}$ Ta data jest sporna. Za początek Frontu Polisario wskazuje się także wydanie przez front manifestu 10 maja $1973 \mathrm{r}$.

${ }^{4}$ „Wszystkie narody mają prawo do samostanowienia; na mocy tego prawa określają według własnej woli swój status polityczny i swobodnie rozwijają swe życie gospodarcze, społeczne i kulturalne” (Deklaracja, 1960). 
włączyć ją do Maroka - o tyle Hiszpańska Sahara stanowiła bardziej złożony problem - zarówno ze względu na sprzeczne roszczenia Maroka i Islamskiej Republiki Mauretanii, jak i brak wiedzy co do rzeczywistych pragnień zamieszkującej Saharę populacji. Dlatego w kolejnej rezolucji wydanej w sprawie Hiszpańskiej Sahary w 1966 r. Zgromadzenie Ogólne wezwało Hiszpanię do przeprowadzenia referendum wśród ludności tubylczej Sahary po konsultacjach z rządami Mauretanii i Maroko, w którym to referendum ludność saharyjska mogłaby wyrazić swoją wolę w ramach samostanowienia (Resolution 2229, 1966). Hiszpania nie podjęła się przeprowadzenia referendum pomimo tego, że Zgromadzenie Ogólne ONZ wzywało do jego organizacji w sześciu następujących po sobie rezolucjach w sprawie Hiszpańskiej Sahary w latach 1967-1973. Rezolucje w sprawie referendum poparła w 1973 r. Organizacja Jedności Afrykańskiej (OJA) oraz Ruch Państw Niezaangażowanych (Hodges, 1984, s. 91-92).

W związku z naciskiem międzynarodowym, problemami wewnętrznymi (zmierzch epoki Francisco Franco) i wojną partyzancką prowadzoną przez Polisario Hiszpania w sierpniu 1974 r. zgodziła się przeprowadzić referendum zgodnie z żądaniami ONZ. Jednak tym razem zaprotestował król marokański Hasan II (Al-Hasan at-Tani ibn Muhammad). Zagroził on użyciem siły w razie, gdyby Sahara Zachodnia nie weszła w skład Królestwa Marokańskiego (Durch, 1993, s. 155). Podobne roszczenia wysunęła Mauretania. Wobec tego Zgromadzenie Ogólne w tym samym roku przyjęło rezolucję, w której poddawało pod rozstrzygnięcie Międzynarodowego Trybunału Sprawiedliwości (MTS) w ramach opinii doradczej (niewiążącej prawnie) kwestię tego, czy Sahara Zachodnia przed skolonizowaniem przez Królestwo Hiszpanii była terytorium niepodlegającym niczyjej władzy państwowej (terra nullius). Jeżeli zaś odpowiedź MTS byłaby negatywna, to kolejna kwestia odnosiła się do tego, jakie były związki tego terytorium zarówno z Królestwem Marokańskim, jak i z Mauretanią w okresie bezpośrednio poprzedzającym kolonizację (Resolution 3292, 1974).

Innym działaniem podjętym wówczas przez ONZ było wysłanie w 1975 r. na sporne terytorium misji specjalnej z zadaniem zbadania sytuacji od strony politycznej i społecznej. W skład delegacji weszli przedstawiciele ONZ pochodzący z Cesarstwa Iranu, Republiki Wybrzeża Kości Słoniowej oraz z Republiki Kuby - takie dobranie składu miało zagwarantować bezstronność misji. Wynikiem pracy delegacji był obszerny raport zawierający przedstawienie roli każdego z państw zaangażowanego w spór oraz opis terytorium i jego mieszkańców. 
Raport nie wzbudził jednak szerszego zainteresowania w społeczności międzynarodowej ze względu na brak wskazania jednoznacznego rozstrzygnięcia sporu o Saharę Zachodnią (Malinowski, 2001, s. 252260).

MTS w opinii doradczej wydanej 16 października 1975 r. stwierdził, że przed hiszpańską kolonizacją Sahara Zachodnia nie była terytorium niepodlegającym niczyjej władzy ze względu na obecność ludności koczowniczej zorganizowanej politycznie i społecznie w plemiona, które były reprezentowane przez wodzów. Odpowiadając na drugie pytanie (co do związków terytorialnych) MTS orzekł, że istniały zarówno pewne związki prawne plemion saharyjskich z sułtanem Maroka, jak i z emiratami i plemionami obecnymi wówczas na terytorium współczesnej Mauretanii, jednakże na podstawie materiałów przedłożonych sądowi nie można potwierdzić zwierzchności terytorialnej nad tym obszarem żadnej ze stron sporu - zatem roszczenia stron nie powinny zakłócić dekolonizacji Sahary Zachodniej (Advisory Opinion, 1975).

Maroko niezwłocznie zareagowało na werdykt MTS - król Hassan II wezwał do ogromnej manifestacji 350 tys. obywateli marokańskich, którzy wyruszyli pod granicę z Hiszpańską Saharą. Hiszpania ustąpiła pod presją Maroka, obawiając się konfliktu zbrojnego (al-Masira al-hara, 2016). 14 listopada 1975 r. zostało zawarte porozumienie trójstronne pomiędzy Hiszpanią, Marokiem i Mauretanią̧ ${ }^{5}$ Na jego podstawie rząd hiszpański zobowiązał się do wycofania się z Sahary Zachodniej. Jej terytorium miało zostać podzielone i w 2/3 przypaść Królestwu Marokańskiemu, a w 1/3 Mauretanii. Do końca stycznia 1976 r. ostatni żołnierze hiszpańscy opuścili Saharę (Hodges, 1984, s. 96-97).

\section{SAHARYJSKA WOJNA WYZWOLEŃCZA}

WKROCZENIE OBCYCH WOJSK DO bY€EJ HisZPAŃSKIEJ SAHARY WYWOŁAŁO REAKCJĘ ugrupowań niepodległościowych z Frontem Polisario na czele. 27 lutego 1976 r. Polisario popierane przez Algierską Republikę Ludowo-Demokratyczną proklamowało utworzenie Saharyjskiej Arabskiej Republiki Demokratycznej (SARD). Wybuchła wojna partyzancka, w której oddziały saharyjskie w ciągu kilku lat zmusiły do wycofania się z konfliktu Mauretanię (Abraz ahdat, 2015). Najsilniejszy przeciwnik Polisario - Maroko zajęło niemal całą Saharę Zachodnią. Do 1987 r. wojska marokańskie zbudowały i obsadziły mur oddzielający

${ }^{5}$ Nazywane także paktem madryckim. 
kontrolowane przez Maroko terytorium Sahary Zachodniej od peryferyjnego pustynnego obszaru, do którego zepchnięte zostały oddziały Polisario (Durch, 1993, s. 156).

Wojna w Saharze Zachodniej wywołała masową ucieczkę ludności w głąb pustyni. Szacuje się, że około połowa Saharyjczyków ${ }^{6}$ (Sahrawi) uciekła przed marokańsko-mauretańską inwazją. Współczesne szacunki co do liczby uchodźców saharyjskich zamieszkujących obecnie obozy uchodźców w Algierii w prowincji Tinduf (Tinduf) oscylują od 180 tys. do 250 tys. (Farah, 2009, s. 92). Sytuacja polityczna algierskich obozów jest wyjątkowa. SARD bowiem, reprezentowana przez Front Polisario, sprawuje suwerenną władzę na ich terenie za przyzwoleniem Algierii do czasu repatriacji uchodźców. Jednym z zewnętrznych oznak odrębności tego wydzielonego terytorium są punkty kontrolne, które pełnią funkcję przejść granicznych i są obsadzone wspólnie przez saharyjskich i algierskich żołnierzy (Farah, 2010, s. 6263).

Do 1985 r. wezwania Organizacji Narodów Zjednoczonych do osiągnięcia porozumienia pomiędzy stronami konfliktu saharyjskiego pozostawały bez odpowiedzi. Doszło w tym okresie do nieoficjalnych rozmów przedstawicieli Maroka i Polisario za pośrednictwem Sekretarza Generalnego ONZ Javiera Péreza de Cuéllar, jednakże nie przyniosły one żadnego znaczącego skutku. Pozorny przełom nastąpił w październiku 1985 r. Rząd marokański przyjął wielokrotnie powtarzaną w rezolucjach Zgromadzenia Ogólnego ONZ propozycję zorganizowania referendum niepodległościowego w Saharze Zachodniej pod nadzorem ONZ (Durch, 1993, s. 156-157). Szybkie zakończenie wojny saharyjskiej leżało w interesie obu stron - dla Maroka konflikt był wyczerpujący finansowo, z kolei sojusznicy i sponsorzy Frontu Polisario stopniowo odwoływali swoje wsparcie dla SARD. Obie strony konfliktu 30 sierpnia $1988 \mathrm{r}$. zaakceptowały zarys planu sporządzonego przez ONZ i OJA, na którego podstawie miało dojść do zawieszenia broni i przeprowadzenia referendum. 20 września 1988 r. plan został zatwierdzony przez Radę Bezpieczeństwa ONZ (Resolution 621, 1988).

Rada Bezpieczeństwa ONZ przyjęła dwa podstawowe dla przyszłego referendum dokumenty - raport specjalny Sekretarza Generalnego z 18 czerwca 1990 r. zarysowujący plan realizacji porozumienia co do referendum oraz uszczegółowiający go raport z 19 kwietnia 1991 r. W raportach przedstawiono harmonogram rozwiązania kon-

${ }^{6}$ W 1974 r. hiszpański spis ludności objął 76,425 Saharyjczyków (Farah, 2009, s. 92). 
fliktu saharyjskiego, który optymistycznie zakładał zrealizowanie założonych celów w czasie krótszym od roku. Zakładano, że przed przeprowadzeniem referendum ONZ tymczasowo przejmie administrację Sahary Zachodniej. Jeżeli ludność saharyjska opowiedziałaby się za niepodległością, to wojska marokańskie byłyby zobowiązane do opuszczenia terytorium Sahary; jeżeli jednak Saharyjczycy wybraliby integrację z Królestwem Marokańskim, wtedy Front Polisario zostałby rozbrojony i zdemobilizowany. Przyjęto, że obie strony podporządkują się wynikowi referendum w czasie od 4 do 6 tygodni. Miesiąc po tym wydarzeniu siły pokojowe zostałyby ostatecznie wycofane, a swoją działalność rozpocząłby Urząd Wysokiego Komisarza Narodów Zjednoczonych do spraw Uchodźców (UNHCR) (Report of the Secretary-General, 1990, s. 43-66; Report of the Secretary-General, 1991, s. 3-6, 12-15).

\section{OBECNY STATUS KONFLIKTU SAHARYJSKIEGO}

Na Podstawie powyższych raportów Sekretarza Generalnego Rada BeZPIECZEŃSTwA powołała do życia rezolucją z 29 kwietnia 1991 r. misję pokojową pod nazwą MINURSO (Mission des Nations Unies pour l'Organisation d'un Référendum au Sahara Occidental) (Resolution 690, 1991). Zakładano, że misja składać się będzie z dwóch komponentów: cywilnego w liczbie osób od 800 do 1000 oraz wojskowego liczącego sobie około 1700 personelu i około 300 policjantów. MINURSO rozpoczęła swoją działalność na terytorium Sahary Zachodniej we wrześniu 1991 r. i jej głównym zadaniem jest nadzorowanie przestrzegania zawieszenia broni, które formalnie weszło w życie 6 września 1991 r., oraz przygotowanie i przeprowadzenie referendum (MINURSO Background, 2015).

Zasadniczym problemem MINURSO od początku jej istnienia było niedofinansowanie. Zakładany pierwotnie budżet misji wynoszący 260 mln dolarów pomniejszono do $177 \mathrm{mln}$ jeszcze przed rozpoczęciem wykonywania zadań. Obecnie wynosi on niemal $56 \mathrm{mln}^{7}$, co czyni MINURSO misją pokojową przeprowadzaną najtańszym kosztem spośród wszystkich aktualnych misji ONZ (Approved resources, 2015). Działalność misji utrudnia także strona marokańska, która nie współpracuje z wysłannikami ONZ i blokuje patrole sił pokojowych. Spośród 185 zarejestrowanych naruszeń zawieszenia broni w sierpniu $1992 \mathrm{r}$.

${ }^{7}$ Budżet przyjęty 14 stycznia 2015 r. na okres od 1 lipca 2014 r. do 30 czerwca 2015 r. 
178 było popełnionych przez Maroko, a zaledwie 7 przez Polisario ( $R e-$ port of the Secretary-General, 1992, s. 4; Durch, 1994, s. 168).

Działalność Komisji Identyfikacyjnej MINURSO, która miała przygotować spis ludności saharyjskiej do referendum, została sparaliżowana przez marokańską administrację. Po zarejestrowaniu 120 tys. potencjalnych głosujących, strona marokańska przesiedliła i zgłosiła 170 tys. nowych Saharyjczyków. Ich wiarygodność była podważana przez urzędników MINURSO, którzy byli zobowiązani do indywidualnego rozpatrywania każdego potencjalnego głosującego. Zgłoszeni przez Maroko tzw. Saharyjczycy najczęściej nie dysponowali żadnymi wiarygodnymi dokumentami, nie posługiwali się saharyjskim dialektem arabskiego (Hassaniya) ani nie posiadali wiedzy nt. specyficznej struktury plemiennej $\mathrm{w}$ regionie. Według relacji członków komisji sprawiali wrażenie, jakby wyuczyli się na pamięć odpowiedzi dotyczących własnej biografii (Bhatia, 2003, s. 809). Rząd marokański zaprotestował wobec nieprzyjęcia wniosków zgłoszonych Saharyjczyków i na tej podstawie nie dopuścił do przeprowadzenia referendum. W raporcie z 25 października 2000 r. sekretarz generalny ONZ Kofi Annan wskazał na brak możliwości wprowadzenia porozumienia co do referendum w życie w związku z brakiem współpracy ze strony Maroka (Report of the Secretary-General, 2000, s. 5-6).

Swoiste zamrożenie konfliktu i wieloletni brak znaczących sukcesów w rozwiązaniu sporu wywołały narastającą frustrację ludności saharyjskiej. Od czasu wprowadzenia MINURSO dochodziło kilkakrotnie do masowych wystąpień, z których jedne z największych miały miejsce w październiku 2010 r. na przedmieściach al-Ujun. Skala i rodzaj wystąpień oraz ich umiejscowienie w czasie pozwala na wpisanie tych wydarzeń do szerszego nurtu tzw. arabskiej wiosny (Lamamra, 2015, s. 37-39). Masowe protesty zarówno w Saharze Zachodniej, jak i w świecie arabskim wywarły presję na rząd marokański. Ratyfikowana w 2011 r. nowa konstytucja marokańska zapoczątkowała zmiany w administracji w kierunku decentralizacji. Saharyjczycy uzyskali wpływ na lokalną administrację oraz zagwarantowano ich prawa do używania własnego języka i kultywowania swojej kultury. Władze marokańskie zapowiedziały także utworzenie autonomii saharyjskiej (Boukhars, Amar, 2011, s. 222-223).

Ewentualna autonomia zaproponowana przez marokańską administrację będzie oznaczała faktyczne narzucenie warunków przez Maroko i nie rozwiąże konfliktu o Saharę Zachodnią. Presja międzynarodowa pozbawiona oparcia $\mathrm{w}$ światowych mocarstwach do- 
tąd nie charakteryzowała się dostateczną skutecznością. Marokański król Mohammed VI (Muhammad as-Sadis ibn al-Hasan) 6 listopada 2014 r. publicznie oświadczy18: „Sahara pozostanie częścią Maroka do końca świata (...) fakt, że Maroko wybrało współpracę w dobrej wierze ze wszystkimi stronami nie powinien być interpretowany jako oznaka słabości ani nie powinien być używany jako podstawa do żądania kolejnych ustępstw (...) inicjatywa dotycząca autonomii to wszystko, co Maroko może zaoferować (...) suwerenna władza Maroka sprawowana nad całym swoim terytorium jest efektywna, niepodzielna i nie podlega negocjacjom" (Report of the Secretary-General, 2015, S. 2).

\section{ZAKOŃCZENIE}

KONCEPCJA REFERENDUM PROMOWANA PRZEZ ONZ JEST DO PRZYJĘCIA PRZEZ strony konfliktu o tyle, o ile gwarantowałaby im zwycięstwo. Wojna wyzwoleńcza lub uzyskanie kontroli nad Saharą Zachodnią jest warunkiem koniecznym dalszego istnienia Frontu Polisario oraz SARD. W razie niepowodzenia w referendum opcji niepodległościowej wojska Polisario prawdopodobnie nie zaprzestałyby walki. Z kolei Królestwo Marokańskie zbyt dużo poświęciło na podporządkowanie sobie Sahary Zachodniej, by nagle ją porzucić. Koniec marokańskiej okupacji oznaczałby upadek władzy królewskiej na fali społecznego niezadowolenia Marokańczyków. Wielu żołnierzy marokańskich zginęło dla koncepcji Wielkiego Maroka obejmującego Saharę Zachodnią, a ludność marokańska była zmuszona do licznych wyrzeczeń. Ponadto wieloletnia działalność propagandowa marokańskiej administracji skutecznie utwierdzała przekonanie o odwiecznej przynależności Sahary do państwa. W obecnych warunkach - bez zaangażowania światowych mocarstw - ONZ nie jest w stanie uzyskać lepszych warunków dla politycznej niezależności ludności saharyjskiej niż autonomia. Okazuje się, że tylko zmiana polityki zagranicznej najbardziej wpływowych państw świata lub destabilizacja w regionie mogą stanowić szansę dla dekolonizacji Sahary Zachodniej. Każdy kolejny rok okupacji czyni sytuację polityczną Saharyjczyków coraz trudniejszą. Nie tylko ze względu na umacnianie się administracji marokańskiej i swoiste oswajanie się społeczności międzynarodowej z sytuacją, lecz także z uwagi na migrację ludności marokańskiej wspieraną przez rząd centralny (Rice, 2010, s. 32). Ta marokańska polityka faktów dokonanych w ciągu kilkudzie-

\footnotetext{
${ }^{8}$ Tłum. M. S.
} 
sięciu lat może doprowadzić do tego, że Sahara Zachodnia utraci swój pierwotny charakter i nie będzie już dłużej krajem Saharyjczyków. Ich prawa historyczne zostaną zastąpione przez prawa ludności, która faktycznie to terytorium zamieszkuje.

Pomimo tego że perspektywy na osiągnięcie głównego celu zakładanego przez ONZ - przeprowadzenie referendum i dopilnowanie realizacji jego wyniku - są niewielkie, to organizacja wiele osiągnęła w zakresie działań na rzecz pokoju w Saharze Zachodniej. Rola ONZ była znacząca. Owocem jej pracy były m.in. rezolucje Zgromadzenia Ogólnego i Rady Bezpieczeństwa, listy dyplomatyczne i inne pisma uzupełniające, obszerne raporty, niemal ukończony spis Saharyjczyków uprawnionych do głosowania w referendum oraz liczne doraźne działania MINURSO. Kwestia samostanowienia Saharyjczyków pozostała tematem debat międzynarodowych i nie została wyciszona przez zabiegi marokańskie. Niedawna wizyta w Mauretanii sekretarza generalnego ONZ Ban Ki-moona podjęta w marcu 2016 r. była okazją do wyrażenia istotnych deklaracji w sprawie Sahary Zachodniej (al$\bar{A} \min , 2016)^{9}$. Poza kwestiami politycznymi należy również wskazać na doraźne działania na rzecz pokoju - monitorowanie przez misję pokojową i obserwatorów terenów okupowanych ograniczyło represje wymierzone przeciwko lokalnej ludności i uskuteczniło zawieszenie broni.

\section{BIBLIOGRAFIA}

Advisory Opinion - Western Sahara (1975), 16 October 1975, International Court of Justice, www.icj-cij.org.

al-Amin A. (2016), Ban: taqrir al-masir dururi fi as-sahra al-garbiya, www. aljazeera.net.

al-Masira al-hadra (2016), www.aljazeera.net 16.03.2016.

Approved resources for peacekeeping operations for the period from 1 July 2014

to 30 June 2015 (2015), UN General Assembly, A/C.5/69/17, www.un.org. Abraz ahdat qadiya as-sahra al-garbiya (2015), www.aljazeera.net. Bhatia M. (2003), Repatriation under a Peace Process: Mandated Return in the

Western Sahara, „International Journal of Refugee Law”, 2003, Vol. 15 (4). Boukhars A, Amar A. (2011), Trouble in the Western Sahara, „The Journal of the Middle East and Africa", 2011, Vol. 2 (2). Clifford J. (2015), The Last Colony: Western Sahara, www.worldpolicy.org.

${ }^{9}$ Christopher Ross, specjalny wysłannik ONZ do Sahary Zachodniej, po raz kolejny otrzymał zadanie doprowadzenia do wznowienia rozmów pomiędzy stroną marokańską a Frontem Polisario. 
Connett D. (2016), Western Sahara: Africa's last colony takes struggle for self-determination to European courts, www.independent.co.uk

Deklaracja $w$ sprawie przyznania niepodległości krajom i narodom kolonialnym, Rezolucja Zgromadzenia Ogólnego 2514 (XV), 14 grudnia 1960 r., www.grocjusz.edu.pl.

Durch W. (1993), Building on Sand: UN Peacekeeping in the Western Sahara, „International Security”, 1 April 1993, Vol. 17 (4).

Farah R. (2009), Refugee Camps in the Palestinian and Sahrawi National Liberation Movements: A Comparative Perspective, „Journal of Palestine Studies", January 2009.

Farah R. (2010), Sovereignty on Borrowed Territory: Sahrawi Identity in Algeria, „Georgetown Journal of International Affairs”, 1 July 2010, Vol. 11 (2).

Güell O. (2015), Western Sahara: Africa's last colony, www.opendemocracy.net. Hodges T. (1984), The Western Sahara File, „Third World Quarterly”, Vol. 6, No. 1.

Lamamra N. A. (2015), Western Sahara Since the Arab Spring: Any Hope for Change?, „Conflict Trends”, 2015 (1).

Malinowski M. (2001), Sahara Zachodnia. Konflikt terytorialny między Marokiem a Hiszpania $w$ latach 1956-1976, Toruń 2001.

MINURSO Background (2015), www.un.org.

Pabst M. (2012), The Western Sahara Conflict, „Scientia Militaria: South African Journal of Military Studies", o1 February 2012, Vol. 29.

Report of the Secretary-General on the Situation Concerning Western Sahara (2000), UN Security Council, S/2000/1029, www.un.org.

Report of the Secretary-General on the Situation Concerning Western Sahara (2015), UN Security Council, S/2015/246, www.un.org.

Report of the Secretary-General: on the United Nations Mission for the Referendum in Western Sahara (1992), UN Security Council, S/23662, www.un.org.

Report of the Secretary-General: the Situation Concerning Western Sahara (1990), UN Security Council, S/21360, www.un.org.

Report of the Secretary-General: the Situation Concerning Western Sahara (1991), UN Security Council, S/22464, www.un.org

Resolution 621 (1988), UN Security Council, S/RES/621, Western Sahara, www.un.org.

Resolution 690 (1991), UN Security Council, S/RES/690, Western Sahara, www.un.org.

Resolution 2072 (1965), UN General Assembly, A/RES/2072(XX), Question of Ifni and Spanish Sahara, www.un.org.

Resolution 2229 (1966), UN General Assembly, A/RES/2229(XXI), Question of Ifni and Spanish Sahara, www.un.org. 
Resolution 3292 (1974), UN General Assembly, A/RES/3292(XXIX), Question of Spanish Sahara, www.un.org.

Rice X. (2010), Inside Africa's last colony: betrayed by Spain and oppressed by Morocco, „New Statesman”, Sept 13, 2010, Vol 139 (5018).

Saidy B. (2011), American Interests in the Western Sahara Conflict, „American Foreign Policy Interests”, 2011, Vol. 33 (2).

Williams I. (2015), Morocco's Occupation of Western Sahara Parallels Israel and Palestine United Nations, „Washington Report on Middle East Affairs", 2015, Vol. 34 (8).

\section{SUMMARY}

The author examines the role of the United Nations in process of decolonisation of the Western Sahara. The article describes a modern history of Western Sahara focusing on the UN's policies and activities related to this basing on resolutions, reports and other documents of the organization. The aim of the article is to present UN's decolonisation and conflict resolution activities in Western Sahara. The text shows that the UN has remarkable achievements concerning the people of Sahara, although the main aim - self-determination of Sahrawi people by referendum - currently is unattainable because of idleness of great powers and firm stance of occupying state - the Kingdom of Morocco.

\section{Nota O AUTORZE}

Maciej Skuczyński [skuczynski.maciej@gmail.com] - absolwent Uniwersytetu im. Adama Mickiewicza w Poznaniu na kierunkach prawo i filologia arabska, ukończył Szkołę Podoficerską Wojsk Lądowych w Poznaniu. Jego zainteresowania naukowe obejmują przede wszystkim problematykę stosunków międzynarodowych i polityki państw w regionie Bliskiego Wschodu oraz teorię stosunków międzynarodowych. 